高 Reynolds 数の流れにおける乱れエネルギーのスペクトル特性 Spectral Properties of Turbulence at High Reynolds Numbers

$\begin{array}{llllll}\text { 九州大学工学部 正 員 椿 } & \text { 東一郎 } \\ \text { 九州大学工学部 正 員 小 松 } & \text { 利 } & \text { 光 } \\ \text { 九州大学工学部 } & \text { 正 員 柴 } \text { 田 } & \text { 敏 彦 } \\ \text { 九州大学大学院 } & \text { 学生員 松 } & \text { 本 泰 司 }\end{array}$

\title{
1.まえがき
}

乱れの波数空間に括いて，その中・高波数帯に局所等方性とみなされる平衡領域が存在し，慣性領域では スペクトルのー5/3乗則が成立することが良く知られている。粘性域についても著者らが-13/3 乗則 ${ }^{1)}$.2） を提唱して以来, いくつかの室内実験で-13/3乗則が成立することが報告されている。3).4).5)

一般に次元解析や物理的考察により推測されたスペクトル関数型の妥当性を確かめるためには，べきの勾 配が実験結果と一致するだけでなく、スペクトル定数が広範な条件のもとに一義的に決められていることが

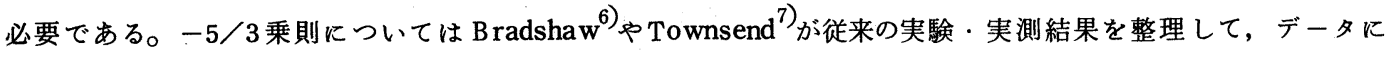
相当のばらつきはあるすのの, 一応スペクトル定数 $\mathrm{A}_{5 / 3}=0.50 \pm 0.05$ を与えている。一方, 粘性域につい ては著者 $5^{8)}$ が開水路乱流や格子乱流の実験を行ない, $-13 / 3$ 乗則のスペクトル定数 $\mathrm{A}_{13} / 3$ と $\mathrm{A}_{5} / 3$ との間の 一義的な関係を求めている。しかしながら室内実験のため乱流 Reynolds 数 $R_{e t}=\sqrt{\overline{\mathrm{u}}^{2}} し / \nu\left(\sqrt{\overline{\mathrm{u}}^{2}}:\right.$ 流れ方向 の乱れ強度, し:積分スヶール， レ：動粘性係数）が比較的小さいデータのみに依っていること，また従来 の $\mathrm{A}_{5} / 3$ の值飞も不確実性が残っていることなどから，正確な $\mathrm{A}_{13} / 3$ の值を確定するには至っていない。

ところで, 最近の乱流が関係した研究に扣いて, 粘性逸散率ををどら算出するかが大きな課題となってい る。従来よりとの算出に際しては(1)慣性域のスペクトルのー5/3 乗則から逆算する方法や(ii)等方性乱れを前 提として逸散スペクトル $\mathrm{k}^{2} \mathrm{~F}(\mathrm{k})$ を波数空間で積分するDryden の方法が用いられてきた。 $-5 / 3$ 乗則がきれ いに成立しているときは(i)は有力な $\varepsilon$ 算出法であるが， Ret 数が小さい流れではー5/3乗則が成立しない 場合も多く，密度勾配の存在する流れでも低波数側のスペクトルは浮力の影響を受けて変形し，慣性域まで その影響を受けることが多い。1).5).99また表面波や内部波の近傍でも波の引き起こす orbital motion により スペクトル形が変形し， $-5 / 3$ 乗則が成立しない場合もみられる。この上らな場合は(i)の方法は使兄ない。 (ii)のDrydenの方法も密度効果を受けると乱れの非等方性が強くなること，また高波数側の noise の影響を 直接受けて過大評価し易いなどの理由で䈌密に使兄ない場合も多い。一方，粘性域の-13/3 乗則は生成域 や慣性域のスペクトルと異なり，高波数のため，浮力や波の影響を受けずに成立する゙）ことから成層流や波 の近傍に颃いてもとの算出に応用することができる。そのためにもスペクトル定数 $\mathrm{A}_{13 / 3}$ の正確な決定が望 まれている。

このよらな背景から，今回Ret の大きな流れの測定を試み，遠賀川河口堰での実測を1984年10月 $23 \sim$ 24 日にかけて行なった。最近の乱流計測技術の発達によりスペクトルの粘性域の測定自体はそれ程難しくは ないが, 実測の場合乱れが広い波数成分に拡がっており、エネルギーも慣性域と粘性域だけです 6 decade 飞渡っていること，また最終的な目標を $\mathrm{A}_{13} / 3$ の值の決定ておいていることなどから，できるだけ高い $\mathrm{S}-\mathrm{N}$ 比のデータを得るため,いくつかの新しい測定方法を採用した。本論文は, これらの実測結果から得られた 高い乱流 Reynolds数の乱れのスペクトルの平衡領域の特性について考察を加えている。

\section{2. 遠賀川河口堰と現地計測の概要}

$2 \cdot 1 \quad$ 遠賀川の河口堰について

遠賀川は馬見山（標高 $978 m$ ）飞源を発し，筑豊炭田を東北に貫流し，直方市に至って大分県境英彦山を 水源とする支川彦山川を合せ，更に犬鳴川等の支川を合せて北部九州を北上し，響灘に注いでいる一級河川 
である。遠賀川河口堰は河道の洪水柾通能力の增大と塩害の防除を計ると共に, 新規都市用水の確保を図る ため, 河口ょり $2.0 \mathrm{Km}$ 地点に設置されており，幅は約 $517 \mathrm{~m}$ である。この河口堰の側岸に魚を通過させるた めの魚道が設置されており，常時放流されている。

今回の乱れの計測はこの魚道の流れを対象にして行なわれたが，ここを測定地点として選んだ理由は以下 のよらである。(i)乱れの計測に hot film流速計を用いたが, hot film流速計を用いる際の大敵は気泡と 水の污れであり, 特に気泡には細心の注意が要 求される。この河口堰で一担湛水された河川水 が魚道を通って流れて来るわけであるが, 湛水 されてほぼ静止している間に気泡は上昇して除 去されていることが期待される。(ii)魚道（写真 -1)は，断面がきれいな矩形となっており好 都合である。(ii)魚道の流量は下流側飞設けられ た 3 段の可動堰により行なわれるが，上流の水 位はほとんど変化しないため, 堰の上下により 希望する流速が得られる。

$2 \cdot 2$ 計測条件と計測方法

計測を行なった魚道（図ー1）は幅 $3.5 \mathrm{~m}$,

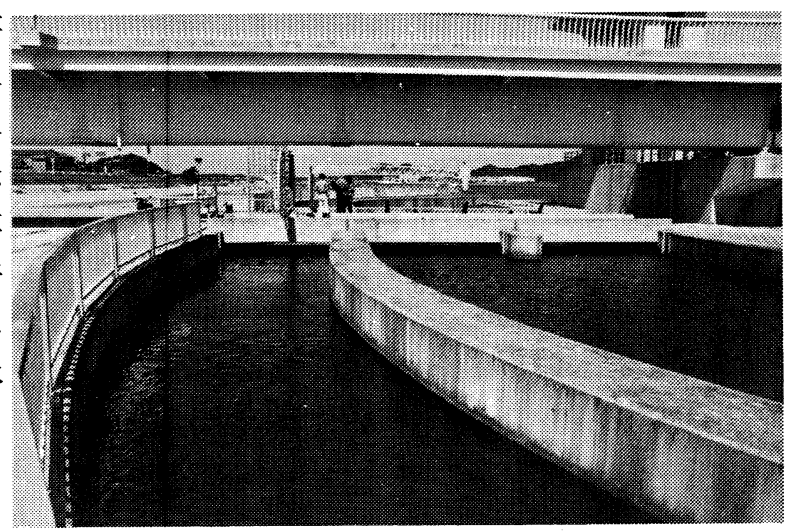

写真 -1 測定地点 高さ $1.8 \mathrm{~m}$ でゆるくカーブしているが 測定地点の上流約 $5 \mathrm{~m}$ は直線水路とな っている。今, 座標を水表面を原点と して流れ方向 $\mathrm{x}$, 鉛直下向きに $\mathrm{z}$, 奥 行方向に $\mathrm{y}$ とする。水深は下流の堰の 上下により若干異なるが約 $\mathrm{h}=1 \mathrm{~m}$, 平均流速は $\mathrm{U}=10 \sim 20 \mathrm{~cm} / \mathrm{s}$ である。平

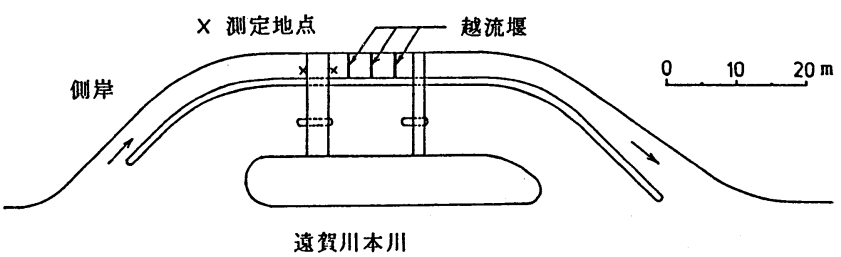
均流速や乱れの測定には 1 日目は日本科学工業社製 1 方向コニカル hot filmプローブ(受感部の大きさ約 $0.5 \mathrm{~mm}$ )を用い, 2 日目は D I S A 社製V 型 2 方向 hot filmプロープ（受感部の大きさ約 $2 m m$ )を使用して, 乱れ $\mathrm{u}, \mathrm{w}$ 測定し, また軸方向に 900 プローブを回転させて乱れ $\mathrm{u}, \mathrm{v}$ 測定した。測線は側壁から水路 幅の $1 / 3$ 程度のところに固定し, 水深方向に $z=0 \sim 45 \mathrm{~cm}$ とした。断面平均の Reynolds 数は $\mathrm{Re}=\overline{\mathrm{U}} \mathrm{h} / \nu=$

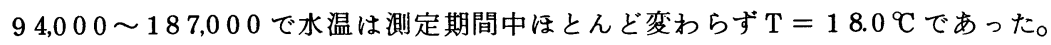

この実測ではデータの $\mathrm{S}-\mathrm{N}$ 比を高めるため, 平均流速を求めるためのデータ(a)と乱れの成分を精度良く 求めるためのデータ(b)，そしてェネルギーレベルの低い高周波（高波数）成分だけを取り出すデータ(c)とに 分けて収録した（四一）。すなわち，(a)のデータはhot film流速計（CＴＡ）からの生のデータで，(b)の データは平均量を差し引いた乱れの成分 だけを取り出し、データレコーダの許容 入力範囲ぎりぎりまで増幅（ 1 ～ 3 倍 $)$ して収録した。また(c)のデータは高周波 の乱れの特性を精度良く得るためにエネ ルギーレベルの高い低周波の成分を high-pass filterで除去した後, やはり データレコーダーの入力範囲ぎりぎりま で増幅（10４0倍）して収録した。(b)，(c) のデータルついてはモニターとして $2 \mathrm{ch}$

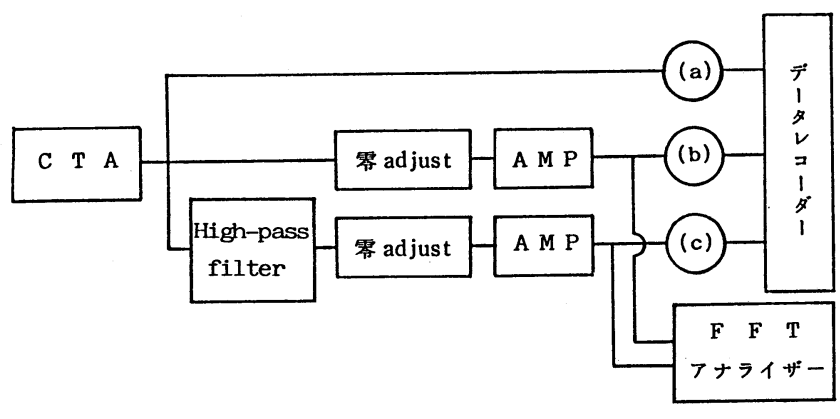

図ー2 データの収録方法 
FFT Spectrum Analizer (小野測器侏製) に入力させ, displayされ たスペクトルを見ながらhigh-pass filterのcut の境界を決定した。 測点によって多少変わるが多くの測点で $10 \mathrm{~Hz}$ を採用した。ここで使用し た high-pass filter はactive filterで内部にコンデンサーを使用して いるため，周波数により位相特性に違いが生じる。これは $1 \mathrm{ch}$ だけの測 定の場合は問題ないが $2 \mathrm{ch}$ 場合は両データの加減から $\mathrm{u}, \mathrm{v}(\mathrm{w})$ を求める ため無視できない。したがってこの問題を避けるため両 chに全く同じ構 造の high-pass fiIterを使用して, 同じ周波数に対しては同じ位相特性 の変化が得られるよらにした。

\section{$2 \cdot 3$ データ処理}

データレコーダーに収録されたデータの時系列の 1 例を図ー 3 に示す。 これらのデータは A - D変換の後, 統計処理された。サンプリング間隔 は $\Delta \mathrm{t}=1 / 375 \mathrm{sec}$, データ個数は 1 測点につき $\mathrm{N}=16,384$ 個である。

スペクトルはF F T 法で計算し, 周波数空間から波数空間への変換は Taylorの凍結乱流の仮定を用いた。得られたスペクトルの 1 例を図ー4 に示す。(b), (c)のデータにより高波数のスペクトルが精度良く得られて いることが良くわかる。

なお，測定 1 日目は川上から川下への風が強く, その為風波が生起さ れ，その波が魚道に進入・伝搬していた。2 日目はほぼ無風状態であっ た。後にデータを解析して初めて明らかとなったのであるが, 1 日目の データは波によって引き起こされた orbital motionによりスペクトル の慣性域に相当する領域に顕著なピークが見られ，-5/3 乗則の成立が 明らかでなかった。そこで本論文で用いたデータは全て波の影響のない 2 日目のV型hot filmを用いて測定したデータを採用した。

\section{3. 実測結果とその考察}

\section{$3 \cdot 1$ 平衡領域のスペクトル}

測定断面の平均流速分布は $z=0 \sim 45 \mathrm{~cm}$ 範囲でしか測定していない ので全体像は良くわからないが，測定された範囲ではほぼ一様の流速分 布を示していた。(b), (c)のデータより得られたスペクトルをhigh-pass filterのcut の境界よりやや高波数の両者のスペクトルが良く一致する 領域で連結し，低波数側を(b)から計算されたスペクトル，高波数側を(c) から計算されたスペクトルで表わせば広い波数域に渡る高精度のスペク トルが得られる。 uのスペクトルの代表的な 1 例を図ー 5 に示す。慣性 域でー5/3, 粘性域でー $13 / 3$ の勾配と良く一致している。このときの乱 流 Reynolds 数はRet $=1,525$ であるが高Ret 数のスペクトルの特徴として - $5 / 3$ 乗則の慣性域が広い波数帯（およそ 2 decade）に渡って成立して いることが注目される。他の測点のスペクトル（Ret $=964$ 4,343）も 同様であった。

\section{$3 \cdot 2$ 慣性域の $\mathrm{A}_{5 / 3}$ と粘性域の $\mathrm{A}_{13} / 3$ の間の関係}

スペクトルの平衡領域では $\varepsilon$ とが支配パラメーターであることから $\varepsilon$ とで無次元化されたスペクトルと波数は単一曲線で普遍表示される ことになる。したがって，粘性域で著者らが提唱しているー13/3 乗則

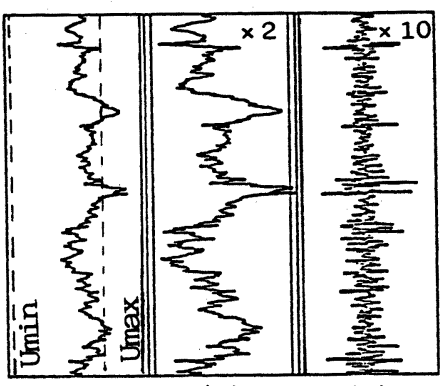

(a)

(b)

(c)

図 - 3 乱れ変動の計測データ

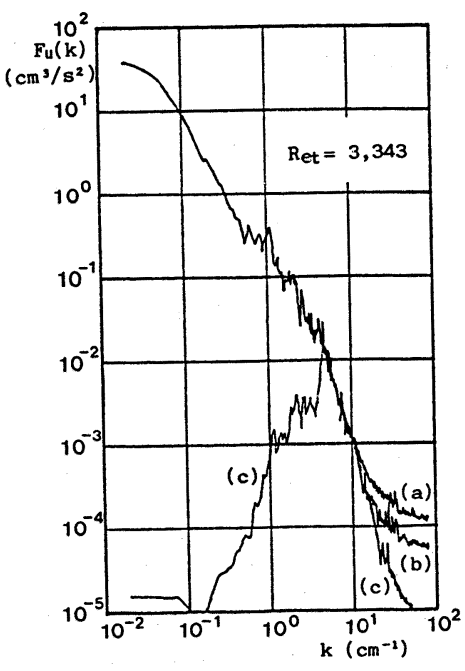

図-4 乱れのスペクトルの 1 例

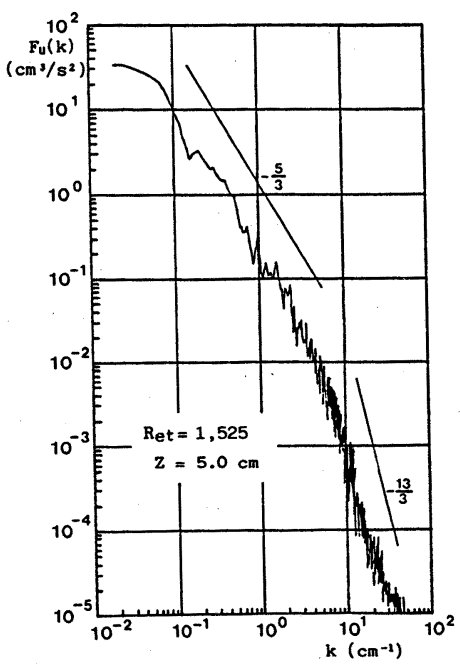

図ー $5 \quad \mathrm{u}$-変動のスペクトル 


$$
\mathrm{F}(\mathrm{k})=\mathrm{A}_{13 / 3} \varepsilon^{4 / 3} \nu^{-2} \mathrm{k}^{-13 / 3}
$$

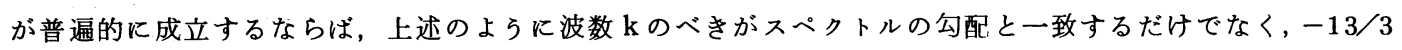
乗則のスペクトル定数 $\mathrm{A}_{13} / 3$ が慣性域の $-5 / 3$ 乗則のスペクトル定数 $\mathrm{A}_{5} / 3$ と一義的に結びつけられなければ ならない。

今, 流れ方向 $\mathrm{u}$ の慣性域のスペクトル

$$
\mathrm{Fu}(\mathrm{k})=\left(\mathrm{A}_{5} / 3\right) \mathrm{u} \varepsilon^{2 / 3} \mathrm{k}^{-5 / 3}
$$

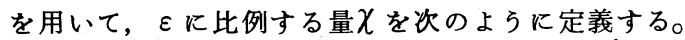

$$
\chi \equiv\left(\mathrm{A}_{5} / 3\right)_{\mathrm{u}}^{3 / 2} \varepsilon=\left\{\mathrm{k}^{5 / 3} \mathrm{~F}_{\mathbf{u}}(\mathrm{k})\right\}^{3 / 2}
$$

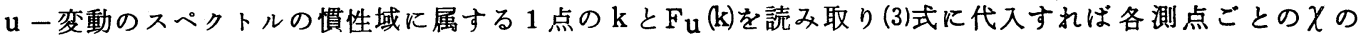

值が算出される。

粘性域の-13/3乗則の式(1)を変形し， $\varepsilon$ の代わりに $\chi$ を用いて表わすと次式のよらになる。

$$
\mathbf{k}^{13 / 3} \nu^{2} \mathrm{~F}(\mathrm{k})=\mathrm{A}_{13 / 3} \varepsilon^{4 / 3}=\left\{\mathrm{A}_{13 / 3} /\left(\mathrm{A}_{5} / 3\right)_{\mathrm{u}}^{2}\right\} \chi^{4 / 3}
$$

$\mathbf{u}$ 一変動のスペクトルについては, 定数 a を次のように定義する。

$$
\mathrm{a} \equiv\left(\mathrm{A}_{13 / 3}\right) \mathrm{u} /\left(\mathrm{A}_{5} / 3\right)_{\mathrm{u}}^{2}=\mathrm{k}^{13 / 3} \nu^{2} \mathrm{~F}_{\mathbf{u}}(\mathrm{k}) / \chi^{4 / 3}
$$

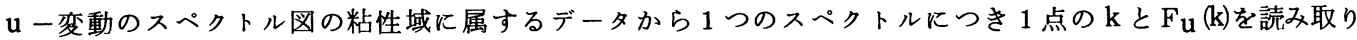
(4)式に代入して a の值が求められる。各々の uのスペクトルから求められた a 值は若干の散らばりはある がほぼ一定値となっており，16 個の平均を取ると

$$
\mathrm{a}=0.047 \pm 0.010
$$

すなわち, $\left(\mathrm{A}_{5} / 3\right) \mathrm{u}$ と $\left(\mathrm{A}_{13 / 3}\right) \mathrm{u}$ の間の関係は次のようになる。

$$
\left(A_{13 / 3}\right) u=(0.047 \pm 0.010)\left(A_{5 / 3}\right)_{u}^{2}
$$

この関係は, 著者 $\left.{ }^{8}\right)$ が開水路乱流や格子乱流, また振動格子乱流の数多くの実験から得た結果と良く一致し ている。 a が一定値となることからRet 数の大きい乱れでも粘 性域で(1)式の-13/3 乗則が良く成立していることがわかる。

$\mathrm{k}$ と $\mathrm{F} \mathbf{u}(\mathrm{k})$ をとレで無次元表示して図ー 6 に示す。若干の 散らばりはあるがほぼ 1 本の線で普遍表示できることがわかる。 なお，勾配は慣性域でー $5 / 3$, 粘性域でー $13 / 3$ にれいに一致 している。

\section{$3 \cdot 3$ 乱れの局所等方性について}

Kolmogoroff（ 1941 )により普遍平衡理論が提唱されて以来 局所等方性は乱流理論の重要な根幹をなすものとして今日まで 受け入れられて来た。しかしながら室内実験では高いRe $\mathrm{e}$ 数の 実験が容易でないことから実験による局所等方性の直接的な検 証は少ない。スペクトルに関してはGrant, Stewart \& Moill iet ${ }^{10)}$ が海峡における潮流の乱れの測定から,またGibson ${ }^{11)}$ が round jet の乱れの測定から各方向の乱れの慣性域のスペク トルを比較検討して，慣性域で等方性が成立することを示して いる。ここでは今回得られた高 Ret 数の乱わのスペクトルから 慣性域だけでなく粘性域について局局所等方性について検討を 加えてみる。

等方性乱流の場合, 主流方向の乱れのスペクトル $\mathrm{Fu}(\mathrm{k})$ とそれ に直角な方向の乱れのスペクトル $\mathrm{F}_{\mathrm{V}}(\mathrm{k}), \mathrm{F}_{\mathrm{W}}(\mathrm{k})$ は次式で関係付 けられる。

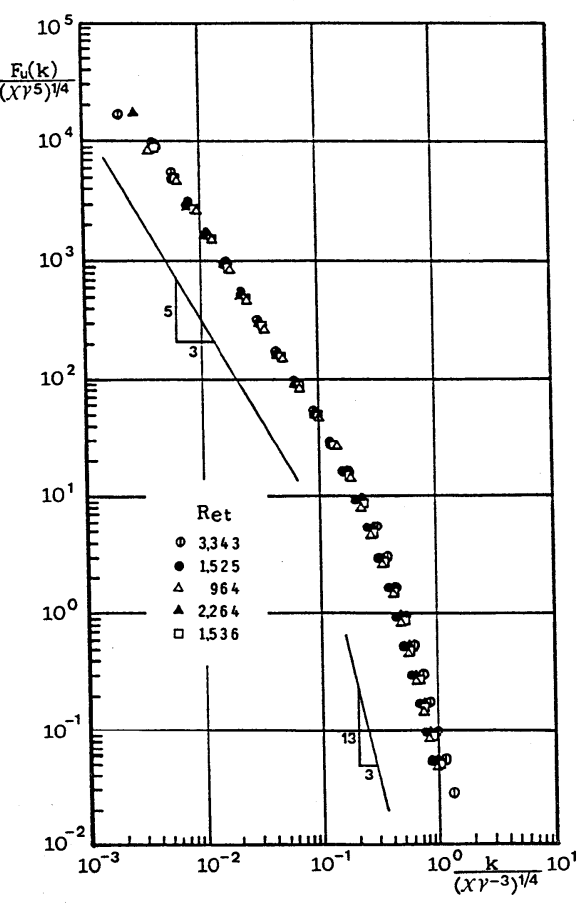

図-6 $\mathrm{u}$-変動のスペクトルの無次元表示 


$$
\frac{\mathrm{d}}{\mathrm{dk}} \mathrm{F}_{\mathrm{v}}(\mathrm{k})=\frac{\mathrm{d}}{\mathrm{dk}} \mathrm{F}_{\mathrm{w}}(\mathrm{k})=-\frac{\mathrm{k}}{2} \frac{\mathrm{d}^{2}}{\mathrm{dk}^{2}} \mathrm{~F}_{\mathrm{u}}(\mathrm{k})
$$

したがって u, v, wの慣性域のスペクトル

$$
\mathrm{F}(\mathrm{k})=\mathrm{A}_{5} / 3 \varepsilon^{2 / 3} \mathrm{k}^{-5 / 3}
$$

を(6)式に代入すると次の関係が得られる。

$$
\left(A_{5 / 3}\right)_{V}=\left(A_{5 / 3}\right)_{W}=\frac{4}{3}\left(A_{5 / 3}\right)_{u}
$$

一方, 粘性域については(1)式の-13/3 乗則を(6)式に代入して

$$
\left(A_{13 / 3}\right)_{v}=\left(A_{13 / 3}\right)_{w}=\frac{8}{3}\left(A_{13 / 3}\right)_{u}
$$

が得られる。

実測から得られたスペクトル $\mathrm{F}_{\mathrm{V}}(\mathrm{k}), \mathrm{F}_{\mathrm{W}}(\mathrm{k})$ をとレで無次元 化して図ー7, 図-8に示す。多くの測点でのスペクトルがと もに 1 つの曲線に収束して良くまとまって扣り, 普遍関数表示 されていることがわかる。これらの図には，図－6の $\mathrm{F}_{\mathrm{u}}(\mathrm{k})$ の無 次元表示の慣性域・粘性域から得られる值をそれぞれ $4 / 3$ 倍,

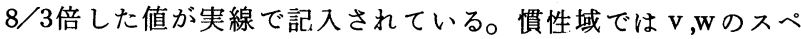
クトルはともに実線と良く一致しており(8)式が成立しているこ とがわかる。粘性域については $\mathrm{F}_{\mathbf{W}}(\mathrm{k})$ は良く一致しているが, $\mathrm{F}_{\mathbf{V}}(\mathrm{k})$ はや小さめとなっている。計算から求めると $\left(\mathrm{A}_{13 / 3}\right)_{\mathrm{V}} /$ $\left(\mathrm{A}_{13} / 3\right)_{\mathrm{u}} \doteqdot 2.0$ 程度で $8 / 3$ よりはやや小さい。この原因は今 のところ明らかではないが，全体としては慣性域・粘珄域の平 衡領域では局所等方性が良く成立していることがわかる。

特に慣性域は FV $(\mathrm{k}), \mathrm{Fw}(\mathrm{k})$ ともに拈よそ 2 decade に渡って(8) 式を満足する $-5 / 3$ 乗則が成立している。これは Ret 数の小さ い室内実験から得られる $\mathrm{v}, \mathrm{w}$ のスペクトルでは汪とんど(8)式が 成り立たず， $-5 / 3$ 乗則も狭い波数域でしか見られないことを 考え併せると非常に興味深い。

\section{4.むすひ}

乱流 Reynolds 数 Ret の大きい乱れの場を求めて遠賀川河口堰 まで出向き，乱れの測定を行なった。測定した場所が魚道だっ たため hot filmプローブのそばで時折魚影が見かけられた。 魚が hot film プローブに衝突するなどのハプニングはなかった が，様子のよくわからない水中に高価なプローブを設置しなけ ればならないためスリルな富んだ測定となった。スケールの大 きい流れの特徵を生かすため，低波数側の乱れの測定も試みた が，水中の気泡や污れが hot film 付着するため， 2 分以上 の連続測定は困難だった。また，進入して来る風波をどうする こともでさなくて，その影響でデータの半分はダメにしてしま った。ただ，条件の整った室内実験でも操作がそれ程容易とは 思觉ないhot filmプローブを屋外で使用した割には良いデー タが得られたと思っている。

本研究で得られた主要な結論は以下のようである。

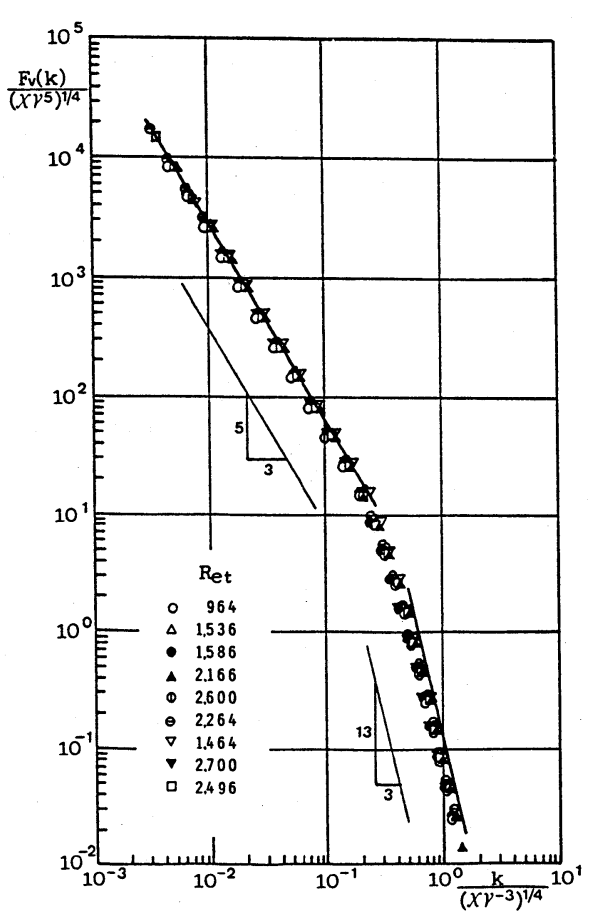

図ー7 $\quad \mathrm{v}$-変動のスペクトルの無次元表示

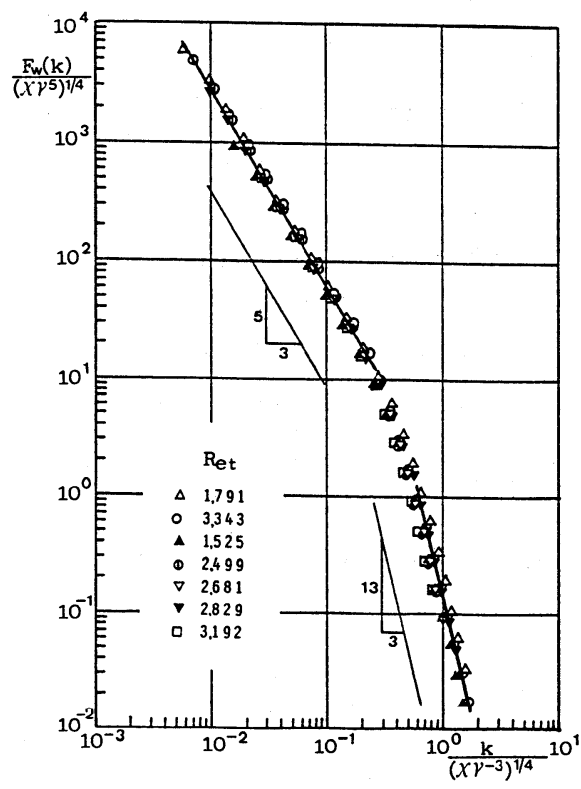

図-8 w一変動のスペクトルの無次元表示 
（1）平衡領域の波数領域だけでも6 decade に渡って乱れエネルギーが分布しているにもかかわらず,highpass filter やアンプを組み合わせることによって高波数まで精度良く測定することができた。

(2) 乱流 Reynolds 数 Ret の大きい乱れでもスペクトルの慣性域ではー5/3 乖則, 粘性域ではー13/3乗則が 良く成立する。特に慣性域の-5/3 乗則は広い波数域に渡って成り立っている。

(3) スペクトル定数 $\left(A_{5} / 3\right) \mathbf{u}$ と $\left(A_{13} / 3\right) u$ の間の一義的な関係が次式のように得られた。

$$
\left(A_{13 / 3}\right)_{u}=\left(\begin{array}{lll}
0.047 \pm 0.010
\end{array}\right)\left(A_{5} / 3\right)_{u}^{2}
$$

これは格子乱流や開水路乱流・振動格子乱流などの室内実験から得られた結果と良く一致する。

（4）各方向の乱れのスペクトルの比較検討から, 乱れの局所等方性が慣性域から粘性域に渡る広い波数域 で成立していることが確認された。

最後に, 九州大学工学部松永信博助手には種々の貴重な助言を受けた。実測に際して献身的な協力を惜し まなかった大学院生仲敷憲和・大串浩一郎の両君にも深甚なる謝意を表します。

また，建設省遠賀川工事事務所河口堰管理支所（笹原一徹支所長）の皆様には終始色々な便宜と御協力を 願った。ここに記して各位に深甚なる謝意を表します。

\section{参考 文 献}

1）椿東一郎・小松利光：成層密度噴流における乱れおよび密度変動のスペクトル特性, 土木学会論文報 告集, No. 268,1977 .

2）小松利光・椿東一郎：平衡領域における乱れ拈よび Reynolds 応力のスペクトルについて, 九大工学集 報, 第 50 巻, 第 4 号, 1977 .

3）椿東一郎・小松利光・下田五郎：2 層境界面に拈ける内部波と乱れに関する実験的研究，第 25 回水理 講演会論文集, 1981 .

4）加藤始・中野晋・池田高則：下層 2 層流の実験(2), 第 29 回海岸講演会論文集, 1982 .

5）鶴谷広一，中野晋・一戸秀久：吹送流による密度界面の混合と乱れ特性，第 31 回海岸講演会論文集, 1984 .

6) Bradshaw , P : Conditions for the Existence of an Inertial Subrange in Turbulent Flow, N.P. . . Aero Rep., $1220,1967$.

7) Townsend A.A. : The Structure of Turbulent Shear Flow, 2nd edition, Cambridge University Press, pp.93 99, 1976 .

8）椿東一郎・小松利光・柴田敏彦・松本泰司：平衡領域における乱れエネルギースペクトルのスペクト ル定数, 土木学会第 39 回年講, 1984 .

9）椿東一郎・小松利光・八尋明彦：成層せん断流における乱流構造, 第 26 回水理講演会論文集, 1982 .

10) Grant, H.L., Stewart, R. W. \& Moilliet, A. : Turbulence Spectra from a Tidal Channel, J.F.M. vol. 12, 1962.

11) Gibson, M.M. : Spectra of Turbulence in a Round Jet, J.F.M., vol. 15, 1963. 